Journal of Jazz Studies vol. 8, no. 1, pp. 1-3 (Spring 2012)

\title{
In Memoriam Steven Strunk (1943-2012)
}

\author{
Henry Martin
}

On February 20, the Journal of Jazz Studies and the music theory community at large lost one of its most congenial and innovative adherents with the passing of Steve Strunk. Steve was a member of the Journal of Jazz Studies Editorial Board, a prime mover in the scholarly study of jazz music theory, a fine composer, an elegant jazz pianist, and a close friend of mine. He was 68 and had taught music theory and composition for 39 years in the Benjamin T. Rome School of Music at Catholic University of America. ${ }^{1}$

The news was shocking, as Steve appeared to be in good health when I saw him in Minneapolis, October 2011, at the annual meeting of the Society for Music Theory. I remember walking with him and my colleague Keith Waters about two miles to a recommended restaurant then back again to the hotel, with no problems whatsoever. In the years I knew Steve he was active and energetic, nor did I ever hear him mention any chronic conditions regarding his health.

At the time of Steve's death, Keith, other colleagues, and I were working with him in preparing for a conference and series of concerts to be held at the University of Oregon from March 2-4, 2012. This event was to be in the memory of Steve Larson, another major contributor to scholarly music theory and a jazz pianist, who had died of a brain tumor in June, 2011. So throughout the winter those of us involved in the Larson conference were emailing Strunk - running ideas for papers by each other, discussing potential topics for roundtable sessions, planning concert repertory, etc. - and then all of a sudden we received the terrible news of his passing. The event at the University of Oregon went on successfully as planned, but with the greatly increased emotional burden and sadness of Steve not being there.

Steve Strunk was a wonderful man, one of the warmest, gentlest people I've ever met. He was so unassuming that not many were aware of his exceptional talent as a composer and pianist and, as a theorist, his important contributions to the field. One of my lasting impressions of him, because I saw it so often, was his close listening to discussions about music. He would freeze

${ }^{1}$ Some information for this remembrance courtesy of an obituary submitted to the Washington Post by members of Steve's family and forwarded to me. copyright by author $(1) \$ \bigodot \begin{aligned} & \text { Except where otherwise noted, this work is licensed under } \\ & \text { http://creativecommons.org/licenses/by-nc-nd/3.0 }\end{aligned}$ 
and lean slightly toward the speakers, focusing intently, trying to grasp every word being said. His comments on the discussion afterwards were usually completely on the mark, elegantly synthesizing whatever was being debated.

As a music theorist, Steve was interested in many topics, but his work on jazz music theory was pioneering. His groundbreaking articles on bebop harmony and melody were an important influence on my work and that of many of my colleagues in jazz theory. I first became aware of him through his contributions to the Journal of Jazz Studies. His articles on bebop harmony (Journal of Jazz Studies 6.1, 1979) and bebop melody (Annual Review of Jazz Studies 3, 1985) very much influenced my own thinking about jazz theory and formed an important basis underlying my 1996 book on Charlie Parker. Steve showed how harmony in early bebop can be generated from a work's overall tonality via transformations that gradually zero in on a tune's actual chord changes. The article on bebop melody analyzed in detail the all-important aspect of voice leading in melodic continuation and harmonic progression. His enumeration in the latter article of the substitution sets that define families of jazz chords is an important contribution that shows why certain chord substitutions work in jazz harmony.

Steve contributed a fascinating article on intervallic patterns in the jazz repertory to the 1996 Annual Review of Jazz Studies 8: Special Edition on Jazz Theory, which I edited. Building off of work by Allen Forte and others, Steve showed how intervallic patterns were important features in some of the most performed and best-known pieces in jazz.

Steve also contributed an important article on jazz harmony to the New Grove Dictionary of Jazz - a remarkable distillation of wide-ranging and complex material into a masterly overview. Here, Steve analyzes harmonic theory and practice in a variety of jazz styles, blending a scholarly approach with practical considerations, i.e., the way jazz musicians themselves think and talk about some of these issues.

Always looking ahead and fascinated by recent developments in scholarly music theory, Steve pioneered the application of neo-Riemannian concepts to jazz theory, as shown in his article on Wayne Shorter's "Yes and No," which appeared in the Dutch Journal of Music Theory 8.1 (2003).

In addition to his scholarly work, Steve was a fine practicing musician, as both composer and jazz pianist. These were distinct worlds for him. After studying at the Berklee College of Music and the Boston Conservatory of Music (where he received his B.M. summa cum laude in 1965), Steve continued to study composition at the Juilliard School of Music. Working with Luciano Berio, Vincent Persichetti, and Roger Sessions, Steve eventually earned his D.M.A. there in 1971. The compositions of his that I've heard reflect mid- 
20th-century modernism and sometimes venture into serialism. His compositions have been performed widely and issued on several CDs, and he has won important grants and residencies. However, as a pianist Steve liked to play the classic American songbook: Berlin, Kern, Gershwin, Porter, Rodgers, and so forth. Thus he was something of a mainstream jazz pianist, but a modernist composer. I asked him once why he didn't work more of his jazz vocabulary into his compositions and he replied that they were separate areas that he preferred to keep separate.

As a jazz pianist, Steve played extensively in the Washington, D.C. area, in all of the top venues and for all of the recent presidents. He once performed with President Clinton. For many years he appeared regularly at the Four Seasons Hotel.

Steve is survived by his wife Elena, two children, and three grandchildren. He was a wonderful man and a great friend. I am among many who will miss him greatly.

\section{ABOUT THE CONTRIBUTOR}

HENRY MARTIN, professor of music at Rutgers University-Newark, is a composer and music theorist. His most recent CD is Selected Piano Music (Albany Records TROY1171), as performed by Hilary Demske. He is founder and former chair of the Interest Group in Jazz Theory of the Society for Music Theory. His Charlie Parker and Thematic Improvisation is no. 24 in the Scarecrow Press Studies in Jazz series. Cengage has just issued the third edition of his jazz history text (coauthored with Keith Waters), Jazz: The First Hundred Years.

The Journal of Jazz Studies (JJS) is published by the Institute of Jazz Studies at the Newark campus of Rutgers, The State University of New Jersey. JJS is hosted online by the Rutgers University Libraries at http://jjs.libraries.rutgers.edu. 